\title{
KNOWLEDGE, ATTITUDE, PRACTICE (KAP) APARATUR SIPIL NEGARA DALAM IMPLEMENTASI NILAI DASAR PEGAWAI
}

\author{
Tiyas Nur Haryani, Okta Hadi Nurcahyono \\ Program Studi Ilmu Administrasi Negara Fakultas Ilmu Sosial dan Politik \\ Universitas Sebelas Maret, Indonesia \\ Program Studi Pendidikan Sosiologi dan Antropologi Fakultas Keguruan \\ dan Ilmu Pendidikan Universitas Sebelas Maret, Indonesia \\ tiyasnurharyani@staff.uns.ac.id
}

\begin{abstract}
Abstrak
Pada rezim pemerintahan Presiden Soeharto sistem pemerintahan Indonesia adalah sentralisasi dan memiliki banyak kritik sebab pemerintahan menjadi otoriter dan terpusat. Segala kebijakan pada rezim tersebut bersifat top down. Rezim Presiden Soeharto berakhir pada tahun 1998 melalui gerakan reformasi oleh civil society. Pasca berakhirnya Rezim Presiden Soeharto tata pemerintahan Indonesia banyak mengalami perubahan, salah satunya dari sistem sentralisasi menjadi desentralisasi. Sistem desentralisasi bertujuan untuk mendekatkan pelayanan publik kepada masyarakat sekaligus memenuhi pelayanan publik yang berkualitas. Kualitas pelayanan publik sangat bergantung pada komitmen para penyelenggara dan pelaksana pelayanan publik. Penelitian ini dilakukan untuk mengukur pengetahuan Aparatur Sipil Negara, sikap dan praktik mereka dalam menjalankan nilai dasar Aparatur Sipil Negara dengan sampel para aparatur negara di Kecamatan Jebres Kota Surakarta. Pemilihan lokasi dilakukan secara purposive area. Data dikumpulkan dengan survei dan disajikan secara statistik deskriptif. Hasil yang diperoleh dari penelitian ini ditemukan fakta pengetahuan para Aparatur Sipil Negara telah mengetahui isi Undang-Undang Aparatur Sipil Negara, tapi masih ada beberapa pegawai (2\%) yang merasa tidak mengetahuinya dan tidak mendapatkan informasi terkait regulasi tersebut sebesar 6\% dari total sampel yang diambil. Selain itu fakta menarik lainnya adalah persoalan anti korupsi dan etika publik yang belum berorientasi pelayanan masih dirasakan belum dilaksanakan secara optimal di lingkungan kerja mereka.

Kata kunci: Sumber daya manusia, Knowledge atitude practice, nilai dasar aparatur sipil negara

Abstract

In the government regime of President Soeharto the Indonesian system of government is centralized and has many criticisms because the government becomes authoritarian and centralized. All policies on the regime are top down. President Soeharto's regime ended in 1998 through a reform movement by civil society. After the end of President Soeharto's regime the Indonesian governance changed a lot, one of them from centralized system to decentralization. The decentralization system aims to bring public services closer to the public while providing quality public services. The quality of public services is highly dependent on the commitment of the organizers and the implementers of public services. This research was conducted to measure the knowledge of the State Civil Apparatus, their attitudes and practices in carrying out the basic values of the State Civil Apparatus with a sample of state apparatuses in Jebres Kota Surakarta. Site selection is done by purposive area. Data were collected by survey and presented in descriptive statistics. The results obtained from this study found that the knowledge of the State Civil Apparatus has been aware of the contents of the Civil State Apparatus Act, but there are still some employees (2\%) who do not know about it and do not get information related to the regulation of $6 \%$ of the total sample taken. Besides other interesting facts is the problem of anti-corruption and public ethics that have not oriented service is still felt not implemented optimally in their work environment.

Keywords: Human resources, Knowledge atitude practice, basic values of civil state apparatus
\end{abstract}




\section{A. PENDAHULUAN}

Indonesia merupakan negara yang menerapkan sistem pemerintahan desentralisasi pasca tahujn 1998. Gerakan reformasi oleh masyarakat sipil yang mendesak perubahan tata kelola negara berhasil mengakhiri rezim pemerintahan Presiden Soeharto yang sudah berkuasa selama 32 tahun. terpuruknya kondisi ekonomi rakyat, tingginya Korupsi, Kolusi dan Nepotisme dan besarnya hutang luar negeri pada masa pemerintahan Presiden Soeharto menjadi kritik untuk pemerintahan Presiden Soeharto. Sistem desentralisasi muncul pasca berakhirnya rezim Presiden Soeharto yang saat itu menerapkan sistem sentralisasi. Sistem desentralisasi memberikan banyak peluang partisipasi bagi para stakeholders; antara lain dalam perencanaan kebijakan/program/kegiatan, keterlibatan dalam pelaksanaan program/kegiatan pembangunan dan meningkatnya peran pengawasan bagi stakeholders.

Selain itu, sistem birokrasi Indonesia juga banyak mengalami perubahan saat era reformasi. Spoil system dirubah menjadi merit system untuk meminimalisir Korupsi, Kolusi dan Nepotisme. Menurut Anggraeni (2014) dalam kajiannya tentang reformasi birokrasi untuk pemberantasan korupsi menyebutkan bahwa rendahnya komitmen pemerintah dalam penyelenggaraan pelayanan publik yang berkualitas dan rentan munculnya tindakan korupsi dapat menurunkan kepercayaan masyarakat terhadap negara. Oleh karena itu penting untuk meningkatan kapasitas pegawai dan hal ini harus menjadi perhatian serius bagi pemerintah pusat. Pelayanan publik menjadi prioritas utama pemerintah untuk meningkatkan kesejahteraan dan mencapai pemerataan dampak pembangunan. Kepegawaian di pusat dan daerah dikelola secara optimal agar kualitas penyelenggaraan pelayanan publik meningkat. Undang-Undang Republik Indonesia Nomor 5 Tahun 2014 tentang Aparatur Sipil Negara menjadi momentum tata kelola pegawai negri di Indonesia. Undang-Undang Republik Indonesia Nomor 5 Tahun 2014 tentang Aparatur Sipil Negara bertujuan untuk penguatan pembentukan birokrasi yang kompeten. Komitmen yang kuat dibutuhkan untuk mensukseskan reformasi birokrasi yang dapat dilakukan melalui sistem pembinaan (Anggraeni, 2014).

Langkah selanjutnya dari pemerintah untuk menata pegawainya adalah melalui moratorium Aparatur Sipil Negara yang direncanakan pada tahun 2014 dan dilaksanakan tahun 2015. Moratorium Aparatur Sipil Negarai menjadi bagian dari pelaksanaan reformasi birokrasi. Moratorium dilakukan untuk efisiensi anggaran publik untuk belanja pegawai dan penataan organisasi pemerintah. Jumlah Aparatur Sipil Negara di Indonesia terus mengalami peningkatan dari tahun ke tahun. Pada tahun 2014 mencapai 4.455 .303 orang, mengalami peningkatan dari tahun sebelumnya sebanyak 4.362.805 (Badan Pusat Statistik Republik Indonesia, 2015).

Pasca moratorium pegawai, setiap isntansi atau organisasi dalam melakukan penataan pegawai atau rekrutmen pegawai harus melakukan analisis jabatan yang dijakukan pada Badan Kepegawaian Negara Republik Indonesia, disetujui oleh Kementerian Pendayaangunaan Aparatur Negara-Reformasi Birokrasi Republik Indonesia dan dengan pertimbangan dari Kementerian Keuangan Republik Indonesia. Langkah penataan pegawai yang lain adalah dengan diberlakukan perubahan SOTK untuk pemerataan jumlah pegawai antar Organisasi Perangkat Daerah di daerah dan Kementrian Lembaga di pemerintahan pusat atau perampingan birokrasi dalam suatu organisai. Jumlah pegawai yang besar belum menjadi jaminan tercapainya good governance dan terpenuhinya pelayanan publik yang berkualitas bagi masyarakat.

Birokrasi di Indonesia masih dihadapkan pada berbagai macam persoalan seperti belum optimalnya kualitas 
penyelenggaraan pelayanan publik, tingginya kasus korupsi dan pelayanan red tape. Kasus korupsi Indonesia masih menduduki posisi tinggi di antara negara-negara lainnya di Asia. Catatan dari Transparency International Indonesia (2015) kasus korupsi di Indonesia di tahun 2014 berada pada posisi 117 dari 175 negara dengan skor 34. Pada tahun 2015 skor Corruption Perception Index naik menjadi 36 dan menduduki urutan 88 dari 168 negara yang dikur (LIPI, 2015). Meski demikian, korupsi masih menjadi salah satu patologi yang harus dihadapi pemerintah dan citizen Indonesia sampai dengan saat ini.

Menjadi menarik untuk mengkaji sumber daya manusia aparatur sipil negara di Indonesia dalam menerapkan nilai dasar pegawai yang terkandung dalam UndangUndang Republik Indonesia Nomor 5 Tahun 2014 tentang Aparatur Sipil Negara. UndangUndang Republik Indonesia Nomor 5 Tahun 2014 tentang Aparatur Sipil Negara yang banyak menyentuh aspek manajemen Aparatur Sipil Negara. Undang-Undang ASN mengatur perihal etika ASN, hak dan kewajiban ASB, sanksi kepada ASN yang melanggar ketentuan yang ditetapkan, nilai dasar ASN yang mengandung nilai-nilai Pancasila, prinsip, peran dan tugas pokok dan fungsi ASN. Penelitian ini memiliki tujuan untuk melihat pengetahuan para Aparatur Sipil Negara terhadap nilai-nilai dasar ASN, sikap dan praktik mereka dalam menjalankan nilai dasar pegawai untuk menghasilkan penyelenggaraan pelayanan publik yang berkualitas.

Penelitian dengan variabel KAP (Knowledge, Attitude, Practice) menjadikan bidang sumber daya manusia sebagai fokus dari penelitian. Sumber daya manusia dalam fokus penelitian ini adalah para Aparatur Sipil Negara negara yang memiliki tugas sebagai pelaksana kebijakan, pelayanan publik dan perekat persatuan bangsa. Kapasitas Aparatur Sipil Negara dalam memberikan pelayanan publik yang berkualitas menarik untuk dikaji untuk analisis KAP (Knowledge, Attitude, Practice). Pada posisi ideal para aparatur sipil negara memiliki pengetahuan, sikap, dan ketrampilan sesuai dengan nilai-nilai dasar aparatur sipil negara yang sudah ditentukan oleh pemerintah. Kinerja pegawai yang baik, dalam organisasi publik, ditunjukkan dengan melakukan pelayanan kepada kepentingan publik yang semakin baik dan memuaskan, hal tersebut dapat dilakukan melalui peningkatan atau menambah pengetahuan knowledge, skill dan attitude pegawai (Akbar, 2015).

Knowledge, attitude, practice mendasari good governance (Achmad, 2007). Jika pemerintah memiliki pengetahuan, sikap dan tindakan yang buruk, maka dapat diubah secara bertahap menjadi baik. Kombinasi antara pengetahuan, ketrampilan dan sikap serta mengembangkan kerangka kerja yang mampu untuk memikat, mempertahankan (retain), mengembangkan (develop), dan memotivasi (motivate) sumber daya manusia birokrasi mampu menghasilkan aparat dengan kriteria appropriate calibre (Farazmand, 2004: 267). Pengetahuan, sikap dan tindakan merupakan esensi dalam mewujudkan good governance.

Penelitian sebelumnya tentang knowledge, attitude, practice dalam bidang pelayanan pernah dilakukan Jung dan Yin (2012) yang melihat KAP dalam konteks pelayanan di hotel, penelitiannya mendapatkan temuan bahwa untuk mengembangkan sikap berbagi pengetahuan di antara personil yang menguntungkan layanan pelanggan, penting bagi pimpinan untuk memberikan contoh sikap suportif, memberikan dukungan aktual dalam bentuk seperti intensif, dan mengembangkan budaya yang mendorong personil untuk mencoba inovasi. Penelitian lainnya milik Florensi (2014) melihat bagaimana pemberdayaan masyarakat desa dalam implementasi kebijakan dana desa dengan menekanakan pada aspek pengetahuan (Knowledge), keterampilan (skill) dan sikap (Attitude). Keterbaruan dari penelitian ini adalah dalam hal kajian terjadap kapasitas sumber daya manusia aparatur sipil negara dengan analisis 
KAP. Penelitian ini mengukur pengetahuan, sikap dan praktik Aparatur Sipil Negara dalam mengimplementasikan nilai-nilai dasar Aparatur Sipil Negara (ASN) yang terdapat dalam Undang-Undang Republik Indonesia Nomor 5 Tahun 2014 tentang Aparatur Sipil Negara dan selanjutanya dielaborasi oleh Lembaga Administrasi Negara (2015) menjadi konsep nilai-nilai ANEKA (Akuntabilitas, Nasionalisme, Etika Pulik, Komitmen Mutu dan Anti Korupsi). Aspek knowledge melihat pada pengetahuan ASN terhadap regulasi Undang-Undang Republik Indonesia Nomor 5 Tahun 2014 tentang Aparatur Sipil Negara dan aksesibilitas informasinya. Aspek sikap (attitude) dan praktik (practice) melihat pada sikap dan praktik para ASN dalam menerapkan nilainilai ANEKA (Akuntabilitas, Nasionalisme, Etika Pulik, Komitmen Mutu dan Anti Korupsi) yang harus diemban oleh aparatur sipil negara.

\section{B. METODE PENELITIAN}

Penelitian ini merupakan jenis penelitian deskriptif kuantitatif dengan metode penelitian survai. Dalam penelitian survai data diperoleh peneliti dari para responden dengan menggunakan kuesioner (Singarimbun, 1989). Penelitian deskriptif memiliki tujuan agar dalam mendeskripsikan data dengan penyajian dalam bentuk deskripsi, gambar, grafik sistematis dan sifat serta hubungan antar berbagai fenomena yang dikaji. Dalam mengumpulkan data, peneliti menggunakan kuesioner tertutup. Populasi dalam penelitian ini adalah Aparatur Sipil Negara (ASN) yang ada ditugaskan untuk memberikan pelayan di Kota Surakarta.

Penelitian ini mengambil sampel ASN yang memberikan layanan kepada masyarakat Kabupaten Jebres. Metode pengambilan sampel (teknik sampling) yang digunakan dalam penelitian ini adalah purposive sampling, yakni teknik penentuan sampel dengan pertimbangan tertentu (Sugiyono, 2004). Kecamatan Jebres termasuk dalam kecamatan terluas dan penduduknya cukup besar dibanding kecamatan lainnya di Kota Surakarta. Di Kecamatan Jebres 1 orang pelaksana layanan publik secara perbandingan kuantitatif harus melayani sebanyak 1.136 penduduk atau perbandungan 1 : 1.136. Sebanyak 122 Aparatur Sipil Negara tercatat di lingkup wilayah administrasi di Kecamatan Jebres meliputi kantor kecamatan dan kantor kelurahan. Dengan margin error sebesar 10\% maka dibutuhkan sampel sebanyak 55 orang ASN di lingkup administrasi Kecamatan Jebres Kota Surakakrta. Perbandingan jumlah responsden di masing-masing kantor kelurahan diambil berdasarkan stratified sampling.

\section{HASIL DAN PEMBAHASAN}

Responden dalam penelitian ini berda pada rentang usia 51-55 tahun sebesar 30\%, kemudian terbanyak kedua adalah para pegawai pada rentang usia 46-50 tahun sebanyak $24 \%$ dan ketiga terbanyak pada rentang usia 41-45 tahun sebesar 13\%. Responden generasi X mendominasi dalam penelitian ini, sedangkan responden dari kalangan generasi $\mathrm{Y}$ jumlahnya masih sedikit yakni $2 \%$ pada rentang usia 20-25 tahun, $2 \%$ pada rentang usia 26-30 tahun. Mengenai latar belakang pendidikan para responden paling besar adalah lulusan sarjana sebanyak $41 \%$. Sedangkan yang mencapai pendidikan pascasarjana adalah para pimpinan sebesar $18 \%$. Grafik 1 menampilkan data usia responden. Selanjutnya grafik 2 menampilkan data responeden dilihat dari latar belakang pendidikan. 

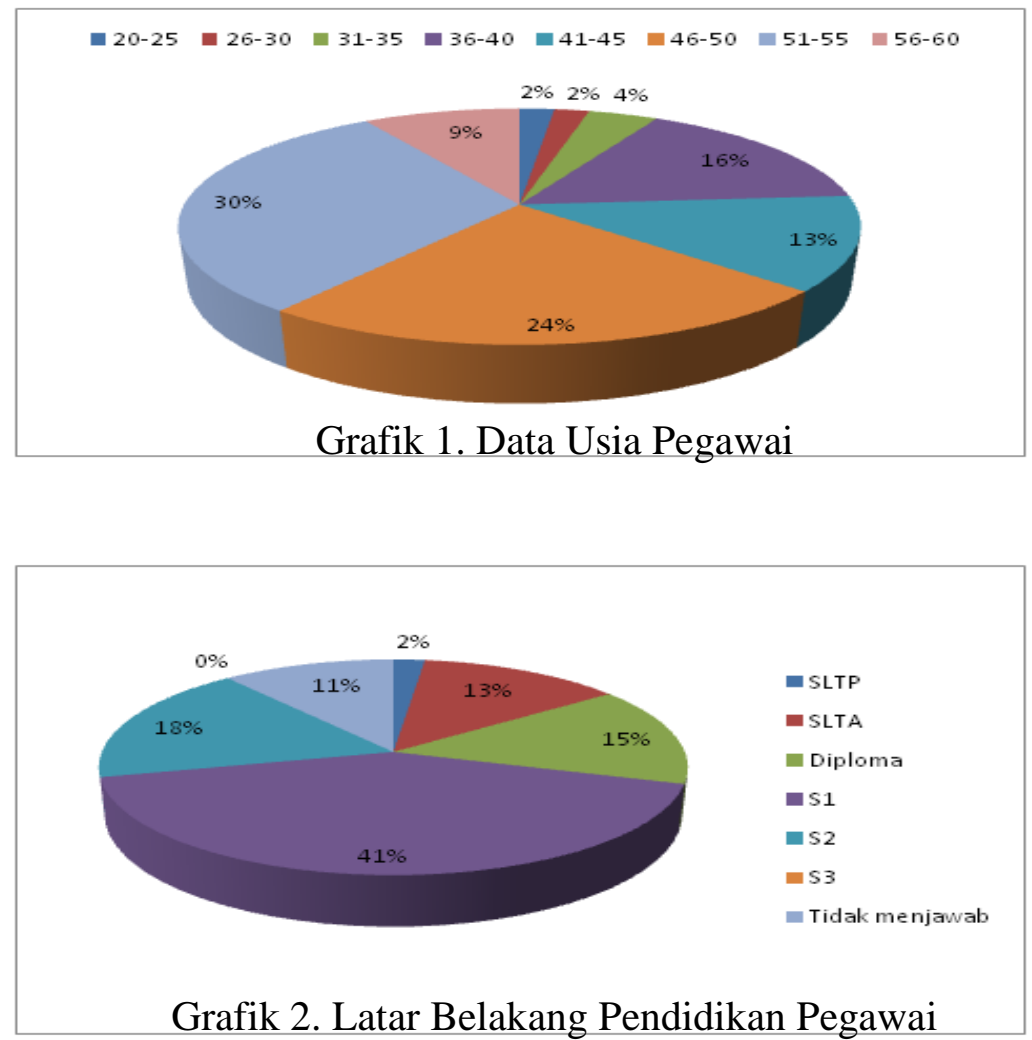

Adapun temuan yang didapatkan dalam setiap variabel dalam penelitian ini antara lain sebagai berikut :

\section{a. Knowledge}

Inti pokok dari kajian ini mendapatkan temuan bahwa hampir semua pegawai kelurahan selaku pelaksana pelayanan publik telah mengetahui Undang-Undang Nomor 5 Tahun 2014 tentang Aparatur Sipil Negara beserta isi regulasi tersebut. Namun, masih terdapat $2 \%$ responden yang mengaku tidak mengetahui perihal Undang-Undang ASN dan tidak mengetahui seluruh isi regulasi tersebut. Hal ini disebabkan karena mereka belum mendapatkan informasi mengenai regulasi tersebut terlihat dari temuan sebanyak $20 \%$ responden mengaku belum pernah mendapatkan informasi peraturan perUndangUndangan yang mengatur kepegawaian di Indonesia.

Media google merupakan media yang paling banyak mendukung kebutuhan informasi para responden. Melalui google meraka dapat mencari dan mempelajari Undang-Undang Nomor 5 Tahun 2014 tentang Aparatur Sipil Negara. selain itu informasi dari kolega membantu dalam sharing knowlegde terkait Undang-Undang Aparatur Sipil Negara. Grafik 3 menampilkan data sumber informasi Undang-Undang No 5 Tahun 2014 tentang Aparatur Sipil Negara. 


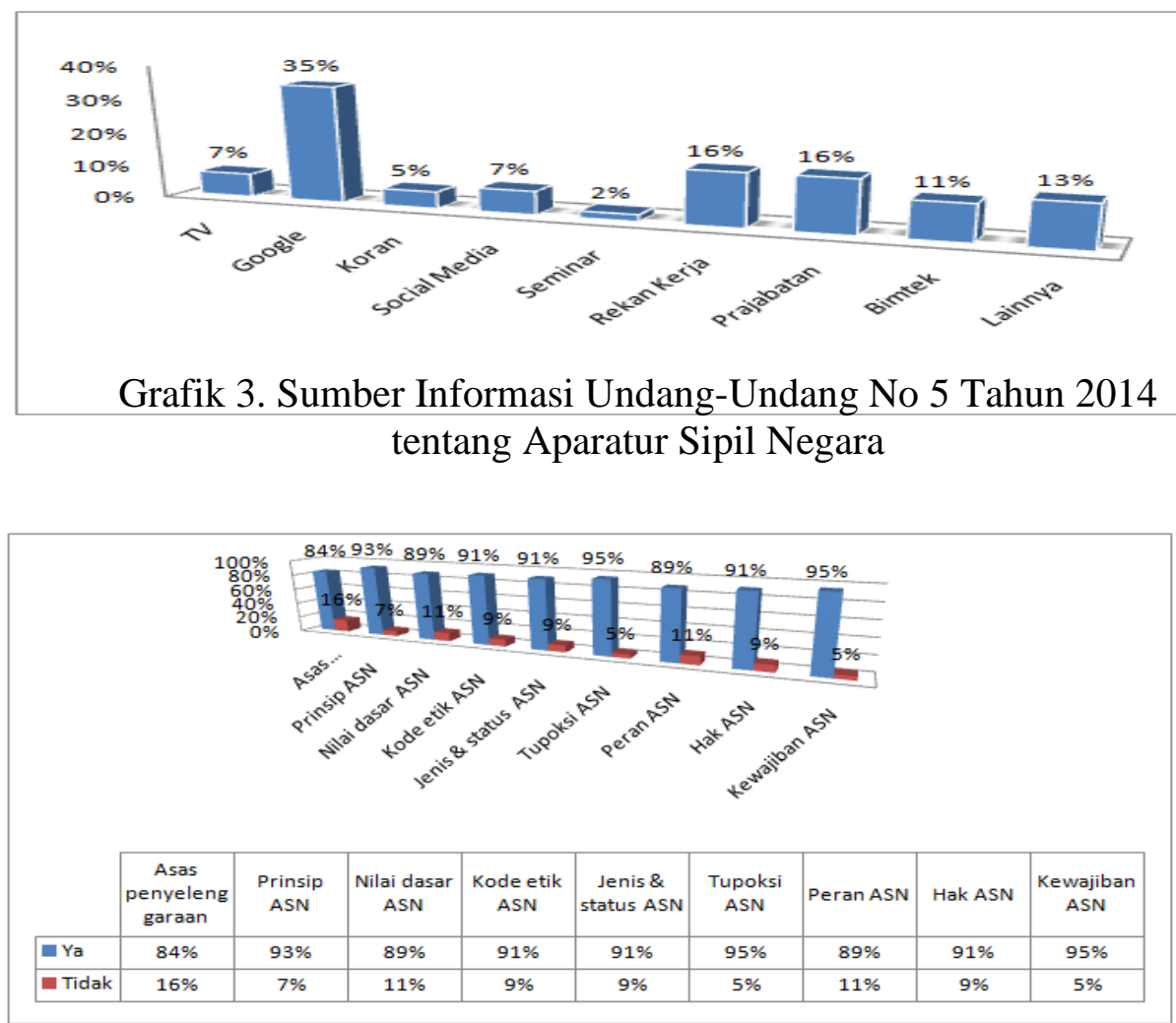

Grafik 4. Pengetahuan Isi Undang-Undang Nomor 5 Tahun 2014

Melihat grafik 4 dapat kita ketahui pengetahuan apa saja yang dominan dikuasai oleh aparatur sipil negara terkait isi UndangUndang No 5 Tahun 2014. Pengetahuan tentang isi regulasi Undang-Undang No 5 Tahun 2014 belum seluruh dikuasai oleh responden. Nilai dasar ASN baru dikuasai sebanyak $89 \%$ responden dan $11 \%$ sisanya tidak mengetahui nilai dasar ASN. Asas penyelenggaraan ASN dipahami oleh $84 \%$ responden dan $16 \%$ responden merasa belum mengetahui asas penyelenggaraan ASN. Pengetahuan terkait prinsip ASN telah dipahami sebanyak 93\% responden, tugas pokok dan fungsi ASN serta kewajiban ASN dipahami sebanyak 95\% responden. Terkait jenis dan status ASN yang mengalami perubahan definisi konseptual dalam UndangUndang Nomor 5 tahun 2014 dipahami sebanyak $91 \%$ responden.

Beberapa pegawai belum menguasai pengetahuan tentang isi Undang-Undang Republik Indonesia Nomor 5 Tahun 2014 tentang Aparatur Sipil Negara bukan tanpa sebab. Terdapat 20\% responden yang mengaku tidak pernah mendapatkan informasi mengenai regulasi kepagawaian tersebut. Sedangkan $74 \%$ responden mendapatkan informasi pada takaran cukup.

\section{b. Attitude and Practice}

Dalam hal sikap terkait nilai dasar Aparatur Sipil Negara, penelitian ini mendapatkan temuan bahwa akuntabilitas masih patut diperhatian secara serius oleh seluruh stakeholders. Akuntabilitas mampu menjadi titik awal dalam membangun budaya kerja yang bersih dari praktik korupsi. Ada $4 \%$ responden yang merasa tidak penting adanya sikap akuntabilitas dalam bekerja dan $34 \%$ lainnya menganggap cukup penting. Hal ini senada dengan hasil penelitian milik Mulyawan dan Dede Mariana (2016) bahwa tingkat pendidikan, pengetahuan, pengalaman, wawasan, motivasi, etos kerja, kualifikasi, kapasitas, dan kompetensi masih cenderung rendah untuk pegawai di tingkat daerah. 


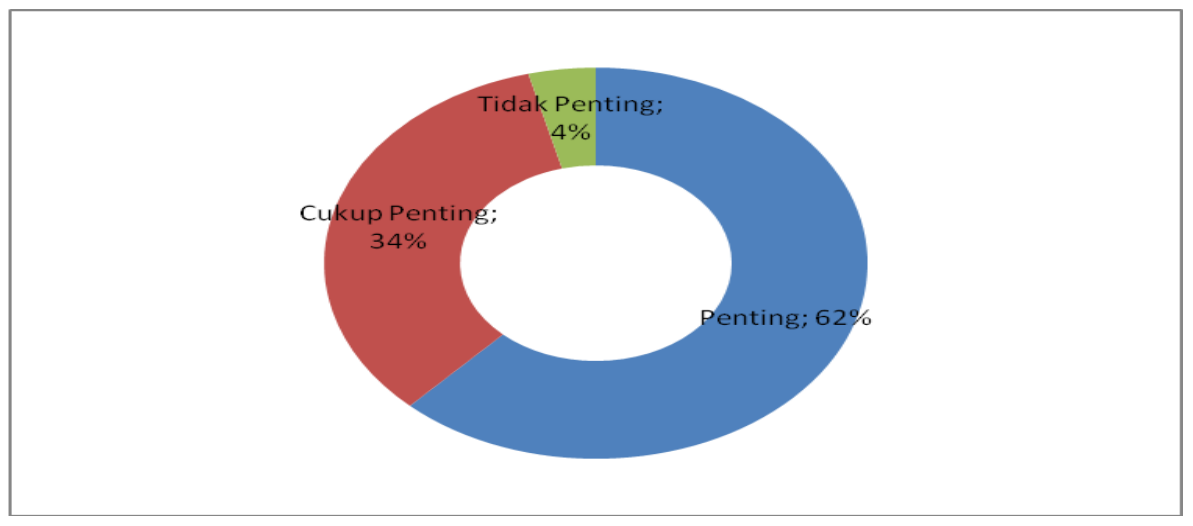

Grafik 5. Sikap Akuntabilitas dalam Penyelenggaraan Pelayanan Publik

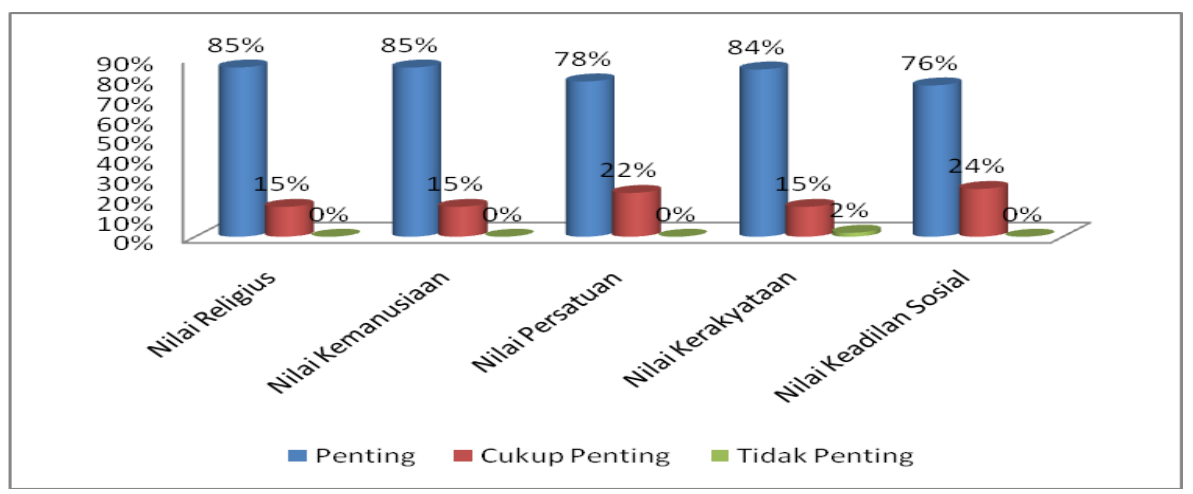

Grafik 6. Sikap Nasionalisme Pegawai

Sedangkan dalam praktik nasionalisme nilai kerakyatan ditemukan ada $2 \%$ responden yang mengangapnya tidak penting meskipun $84 \%$ lainnya menganggap sikap yang bernilai kerakyatan adalah hal yang penting. Secara umum sebagian besar responden menganggap penting sikap akuntabilitas, etika publik dan sikap-sikap nasionalisme bersumber pada nilai Pancasila sebagai dasar negara.

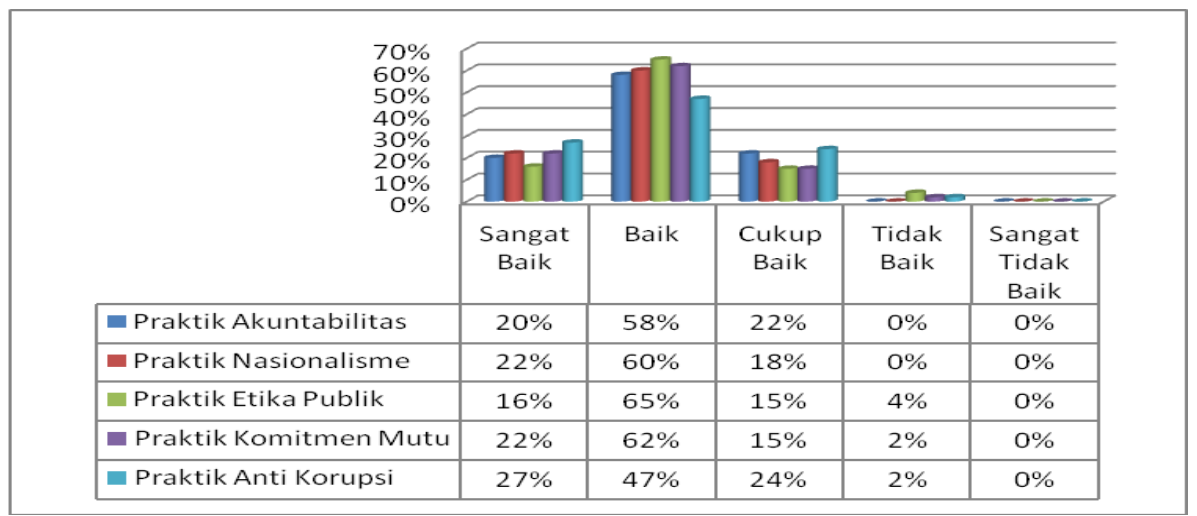

Grafik 7. Praktik nilai-nilai ANEKA

Pada variabel praktik, praktik yang masih belum optimal dalam pelaksanaan penyelenggaraan pelayanan publik adalah praktik anti korupsi, etika publik dan komitmen mutu. Sebanyak $4 \%$ responden mengaku praktik etika publik di lingkungan kerjanya masih tidak baik, 2\% mengaku praktik anti korupsi masih belum berjalan, 
dan 2\% responden mengaku implementasi komitmen mutu masih tidak terlaksana semestinya.

\section{PENUTUP}

Penelitian ini mendapatkan temuan bahwa pengetahuan pegawai negara terhadap regulasi yang mengaturnya belum seluruhnya mengetahui dan memiliki pengetahuan yang kengkap terkait regulasi kepegawaian yang mengaturnya. Keterbatasan pengetahuan tersebut disebabkan oleh masih belum terbukanya akses informasi bagi seluruh lapisan pegawai. Media yang paling efektif untuk meningkatkan pengetahuan pegawai tentang regulasi kepegawaian dan berbagai macam regulasi lainnya adalah via Google dalam Internet. Inisiatif dari para pegawai dalam mengakses informasi menjadi faktor pendukung peningkatan pengetahuan pegawai terkait segala regulasi-regulasi yang mereka butuhkan. Selain itu perbedaan generasi menjadi kesenjangan antar pegawai usia $50 \mathrm{ke}$ atas dan usia muda dalam mendapatkan informasi. Hasil penelitian ini mendapatkan fakta bahwa pegawai usia 50 ke atas lebih tertinggal akses informasi terkini terkain regulasi negara. Sikap dan praktik nilai dasar aparatur sipil negara perlu ditingkatkan integrasinya, mengingat masih ada beberapa responden yang merasa sikap dan praktik nilai dasar pegawai adalah aspek yang tidak penting dalam penyelenggaraan tata pemerintahan dan pelayanan publik. Saran yang dapat kami berikan adalah penanaman nilai dasar pegawai harus dilaksanakan secara berkelanjutan tidak hanya dalam masa pendidikan dan pelatihan kepegawaian. Media-media informasi yang memuat nilai dasar kepegawaian perlu diciptakan di lingkungan kerja untuk mengintegrasikan nilai dasar kepegawaian.

Nilai ANEKA dapat menjadi sebuah budaya kerja bagi Aparatur Sipil Negara (ASN). Integrasi nilai ANEKA dapat diperkuat dalam setiap jenjang pelatihan pegawai sehingga nilai ANEKA bagi ASN tidak luntur di instansi kerja setiap ADN pasca mengikuti pelatihan dan/atau latihan dasar pegawai. Sistem penerimaan dan pengembangan pegawai harus lebih membuka peluang kreativitas dan inovasi dari pegawai sehingga pelayanan publik kepada masyarakat dapat lebih responsif dan berkualitas. Pemerintah daerah lewat Badan Kepegawaian Daerah wajib meningkatkan pengetahuan pegawai pada level menengah dan jenjang posisi paling bawah dalam hal pengetahuan terhadap budaya kerja dan nilai-nilai kerja aparatur sipil negara (ASN).

\section{DAFTAR PUSTAKA}

Akbar, Mohammad. (2015). Penerapan Prinsip Prinsip New Public Management Dan Governance Dalam Reformasi Administrasi. REFORMASI Vol. 5, No. 2, 2015, halaman 1-17

Anggraeni, Tyas Dian. 2014. Menciptakan Sistem Pelayanan Publik yang Baik: Reformasi Birokrasi dalam Pemberantasan Korupsi. Jurnal Rechtsvinding Volume 3 Nomor 3, Desember 2014.

Florensi, Helen. (2014). Pelaksanaan Kebijakan Alokasi Dana Desa (ADD) dalam Memberdayakan Masyarakat Desa di Desa Cerme, Kecamatan Grogol, Kabupaten Kediri. Kebijakan dan Manajemen Publik Volume 2, Nomor 1, Januari 2014. Halaman 118

Mulyawan, Rahman dan Dede Mariana. 2016. Profesionalisme Aparat Dan Kapasitas Kelembagaan Dalam Pelayanan Publik Di Provinsi Jawa Barat. CosmoGov Jurnal Ilmu Pemerintahan, Vol.2 No.2, Oktober 2016 
Ubaidillah, Achmad. (2007). Birokrasi dan Kultur Struktur Rasional-Egaliter: Sumbangan Agama untuk Penguatan Good Governance. Jurnal Studi Agama Vol. VII, No.1 Agustus 2007. Halaman 39-60

Yolanda Ramírez. (2010). Intellectual capital models in Spanish public sector, Journal of Intellectual Capital, Vol. 11 Issue: 2

Farazmand, Ali., (2004). Sound governance: Policy and administrative innovations. Praeger Publishers:Westport, CT.
Jung Chen, Wen dan Yin Cheng, Han.( 2012). Factors affecting the knowledge sharing attitude of hotel service personnel. International Journal of Hospitality Management. Volume 31, Issue 2, June 2012, Pages 468-476.

Singarimbun, Masri dan Effendi, Sofian. (1989). Metode Penelitian Survei. Jakarta: LP3ES

Sugiyono. 2004. Metode Penelitian Bisnis Cetakan Kesebelas. Bandung: CV. ALFABETA. 